Meta

Journal des traducteurs

Translators' Journal

\title{
Layers of Trauma: the Yiddish-Hebrew Fiction of Yosl Birshteyn (1920-2003)
}

\section{Albert Waldinger}

Volume 52, numéro 3, septembre 2007

URI : https://id.erudit.org/iderudit/016730ar

DOI : https://doi.org/10.7202/016730ar

Aller au sommaire du numéro

Éditeur(s)

Les Presses de l'Université de Montréal

ISSN

0026-0452 (imprimé)

1492-1421 (numérique)

Découvrir la revue

Citer cet article

Waldinger, A. (2007). Layers of Trauma: the Yiddish-Hebrew Fiction of Yosl Birshteyn (1920-2003). Meta, 52(3), 434-449. https://doi.org/10.7202/016730ar
Résumé de l'article

Cet article s'est donné deux buts dans sa recherche de l'oeuvre bilingue (yiddish-hébreu) de Yosl Birshteyn, un auteur israelien très estimé en tant que continuateur de Sholem Aleichem : l'étude approfondie de "l'autotranslation ", non seulement dans la traduction d'un texte par l'auteur lui-même, mais aussi comme un critère dans le choix d'autres traducteurs et le dévoilement d'une couche de trauma, le yiddish, sous l' écorce nationaliste, « réussie » et « non cahotante » de l'hébreu. Il voit dans ses « cahoots » une tendresse et une ironie où la souffrance historique pénètre dans la culture, où l'unisson de texte et de soustexte crie d'être traduit dans une langue universelle comme le francais ou l'anglais. 


\title{
Layers of Trauma: the Yiddish-Hebrew Fiction of Yosl Birshteyn (1920-2003)
}

\author{
ALBERT WALDINGER \\ Defense Language Institute, Presidio of Monterey, USA \\ afwald@sbcglobal.net
}

\begin{abstract}
RÉSUMÉ
Cet article s'est donné deux buts dans sa recherche de l'œuvre bilingue (yiddish-hébreu) de Yosl Birshteyn, un auteur israelien très estimé en tant que continuateur de Sholem Aleichem: l'étude approfondie de «l'autotranslation», non seulement dans la traduction d'un texte par l'auteur lui-même, mais aussi comme un critère dans le choix d'autres traducteurs et le dévoilement d'une couche de trauma, le yiddish, sous l' écorce nationaliste, «réussie» et «non cahotante» de l'hébreu. Il voit dans ses «cahoots» une tendresse et une ironie où la souffrance historique pénètre dans la culture, où l'unisson de texte et de soustexte crie d'être traduit dans une langue universelle comme le francais ou l'anglais.
\end{abstract}

\begin{abstract} consequences examined here.

\section{MOTS-CLÉS/KEYWORDS}

Jewish self, Yiddish/Yiddishist, Holocaust, Hebrew, Zionist/Zionism
\end{abstract}

This article evaluates the function of Yiddish-Hebrew creative diglossia in the work of Yosl Birshteyn, a prominent Israeli novelist and short-story writer, particularly in the "first Kibbutz novel" in Yiddish, Hebrew-Yiddish fiction based on the Israeli stock market crash, and the future of Yiddishism in Hebrew and Yiddish. In short, Yiddish acts as a layer of all texts as a fact of communal pain and uncertainty in past, present and future. Birshteyn's Hebrew originals were translated back into Yiddish and his Yiddish work was translated into Hebrew by famous and representative hands with stylistic and linguistic

\section{Emotional and Linguistic Pressures}

Diagnosis of the Jewish self squeezed and strangled by history must clear the way for the literary analysis of the flexible and varied skill of "Autotranslation." (for a basic definition, describing the Yiddish/Hebrew "re-inventions" of Mendele the Bookseller, see Feldman 1986: 15-16). It is absolutely necessary to understand fully that Jewish trauma is inseparable from Jewish life, from the often eccentric "life force" impinging (pinchingly) on today, the lengthened shadow of a shaken yesterday. Accordingly, a society or state created by Jews merely seems to progress smoothly and WW II is much deeper than a merely dated event. It is a datelessly internalized burden in which simultaneously real and fictive characters play out a viscous plot - full of lapses, delays, peaks and seeming nonsequiturs - by casting themselves on the perpetually moving waters of their story.

Thus, although the intrusion of their multidimensional being may dominate the narration, they never lead it to a circumscribed and definite conclusion, to a plain and unambiguous certainty. As Birshsteyn emphasized in a 1976 interview with 
Menakhem Peri, his friend, editor and translator, the Holocaust is a constant but not a simplistic presence; it is a "center" "with various contributory streams flowing from manifold "margins," shockingly differentiated side-effects in thought and behavior (2004: 328, 341, 342,383). Seemingly secondary incidents and verbal resonances, swelling out of the anecdotal into the poetic (Birshteyn/Peri 2004: 335), may surge into the mainstream at the beck and call of the conflicted reader, himself either a victim of Hitler or a modern Israeli faced with constant crisis (see Peri's back page blurb to Birshteyn's Hamutavim (“The Beneficiaries," 2000).

To address him from the distance of more than fifty years - and only three from Birshteyn's future surrender to cancer at the age of 83, Peri the anthologist chose "Veger" (or "Weger," suiting the spelling of its German title character), the story of a WW II survivor. This was a sample of Birshteyn's popularity as a Hebrew writer, one with more than 15,000 sales who made revisions to please his Israeli reader (Peri 2000: $7,22)$. In the course of the interview, Peri had called the story "a touchstone of modern Israeli prose" (2004: 325), even though it was anything but the forecast of an unclouded future.

It is surprising, then, to learn that the story was originally conceived and published in Yiddish (in A mantel fun a prints, 1969 - "The Coat of a Prince"). Also, it is unsettling to revisit the actual scene of the Israeli humiliation of Yiddish, when it was a despised, even "foreign" (and thus non-Jewish!) language; when the Bursteins, stars of the New York Yiddish stage, could tour Israel in the 1950's only to find "Zionist hooligans breaking the theatre windows and the government imposing a special tax on their show, because it was in Yiddish and not in Hebrew..." ("Obituary of Lillian Lux," Economist 2005 [June 25], p.86). Likewise, Birshteyn, a Yiddish writer (and thus, to some extent, a committed Yiddishist), first arrived in Israel from Australia at this time (1950), in a country newly drunken and wobbly with Independence (1948), and met what must have seemed like a second Kristallnacht, the night when the Nazis shattered the windows of Jewish stores. Avraham Shlonsky, a trend-setting Hebrew poet in the literary bohemia of "Little Tel Aviv," had even called the co-existence of the two languages "this catastrophe of bilingualism... We want Israeli breathing to be entirely Hebrew, with both lungs" (emphasis in original, cited in Chaver 2004: 106). In addition, well before him, Haim Nachman Bialik (1873-1934), Israel's "National Poet," had styled such linguistic polyvalence a "tragic phenomena" to which the "reincarnation" of Autotranslation was the painful and necessary solution: "The soul must be transferred from one body to another" (Chaver 2004: 118). By this he could have been thinking of the "soul" (or personality) of Yiddish, in which the "transmigration" was easier and more natural since mame-loshen (the Ashkenazic or European "mother tongue") already contained and retained a host of Hebrew expressions.

Both Bialik and Shlonsky were only repeating Zionist centrality in the "Denial of Diaspora" (Shlilat hagalut) (see Simkhovitch 2006 [Mar. 17]: Forverts, pp. 16-17), which ultimately entailed the boycott and would mean the disappearance of Yiddish, the Diaspora language par excellence. Birshteyn's advocacy attempted to rectify the situation by showing the possibility of creative co-existence, by creating a body of work whose thrust was the intrusion of the "exiled" past into the Zionist present.

He did so first in 1949 while still in Australia preparing to "ascend," while engaged in continuing the Yiddish poetic tradition of his uncle Melach Ravitch, the father of his best friend, the illustrator Yosl Bergner. This turned out to be an extremely prolific 
relationship: not only did Birshteyn become the head archivist of his uncle's work at the Hebrew University of Jerusalem, but he also drew upon Bergner to make expressionistic illustrations for "Veger" once in Israel as well as to his collection of Yiddish poems, "Under Alien Skies," in Melbourne (see Novershtern 2004 [Jan. 9], Haarets, p. 5).

In this collection, Birshteyn imagined his long-suffering Job of a father entering his home as a guest and staying to inhabit his heart (1949: 55). In other words, he was combining the "Our Patriarchs" of tradition (avoteynu) with the "Fathers of the Zionist Settlement" and their socialist morality, especially those of Left Poaley Tsion or the radical wing of the "Workers of Zion" party, and subsequently integrated the creative leaven of biographical relevance as synchronized by Ravitch's "here and now" ideology (“doism," see Waldinger 1999: 70).

Despite the campaign against it, Yiddish remained a buried treasure just waiting to be unearthed. In the late twenties, a good half of the population still read Yiddish newspapers (Chaver 2004: 35) and Mordechai Tsanin, writing in 1950, seemed justified in claiming that the maintenance of a newspaper like his own (Di letste nayes) would enable everyone to participate, especially concentration camp survivors (Estraykh 2005 [Dec.2], Forverts, p.14). Of course, full cultural participation, in Hebrew, was more demanding. Birshteyn, with his ears to the ground like a good "doist," was striving for such empowerment.

He first had to fight against the stereotype of Yiddish as "anti-revolutionary," "reactionary," "anti-Zionist" (Chaver 2004: 40) and somehow trivial and funny, even though Poaley Tsion leaders like David Ben Gurion, a Zionist Father, used it to recruit new members. But these labels can be easily explained: for example, "reactionary" only means "traumatized" (perhaps to the point of paralysis of will), so that Uri Tsvi Greenberg, an important Yiddish poet with Ravitch in the Warsaw of the early 1920's, believed that he could uproot the trauma by rooting his life in Israel (in 1927) and his language in Hebrew. Clearly, he in no way cancelled the plans for Yiddish of Bialik and of Josef Haim Brenner (1881-1921), a pioneer of Hebrew prose. Both held that Yiddish should be preserved, if only as a wounded, scarred and heroic part of the Jewish past and not as a rival of the "clean slate" of Hebrew (Waldinger 2003: 260).

\section{Literary Reworking}

Brenner had even translated Sholem Aleichem (1889-1916) a close contemporary from the Ukraine, and found himself struggling with the formulation of Tevye's folk proverbs, tenderness and sense of Jewish fate in a language of realizable hope, not just of passive "trust" (Yid. Betukhen vs. Israeli He. Bitakhon, also meaning "security") that God would command day out of the darkness. There were, likewise, shtetl ('Jewish village') characters: in Sholem Aleichem's Blonzende shteren ("Wandering Stars"), for example, there are two fathers, one rich and one poor, one robust and despotic and one bedraggled and weak (suggesting that the social polarizations of Sholem Aleichem, in contrast to Birshteyn, may well have been "petit bourgeois," see Roskies 1995: 374/ n.10). There are two mothers, the second a classic worrier, and a pair of Nineteenth Century juvenile and ingénue lovebirds who travel throughout Romania as members of a theatrical troupe (like that of Avrom Goldfaden?) managed by a populist clown (1999: 6, 20, 21, 37). 
All of these are caricatures but they are felt as having real warmth - even the scolding has a genuine caring (Sholem Aleichem 1920: 6, 118); the "Jewish sighs" of Sholem Aleichem's parent characters (even in such a late work as Motl Pesye dem khazns 1920, translated as the Adventures of Mottel the Cantor's Son by Tamara Kahana in 1953) are not merely the automatic reflexes of pain. Accordingly, Sholem Aleichem, somewhat like Birshteyn afterward, is much more than the "wielder of a pen"; he offers a "shoulder to cry on," not a mere plot. Thus, an eccentric in "The Beneficiaries" sees him as a "friend" while the central character of the book heads his museum with the portrait of a writer known as a man of the people (2000: 89).

Nevertheless, as Roskies (1995) tells us, Sholem Aleichem's representations of "the mundane" were only stylized, the stuff of myth rather than reality (154). They were too dense, too salient, too exaggerated to be "true to life." Birshteyn, on the other hand, is laconic and unvarnished in, for example, his descriptions of the "strange nomads" (Novershtern's 2004 expression) on a Jerusalem bus. These are, in fact, the "little people" (Di kleyne mentshalakh) of Sholem Aleichem, but they have been translated to Israel, where it is no shame to be a beggar (in fact, Ben Gurion would have called it a healthy sign of normalcy and Birshteyn might have agreed). For this reason, in a brand new environment, Novershtern places him in the tradition of Sholem Aleichem's "Railroad Stories" in which the Yiddish master rendered the Jewish passengers of a third-class compartment (2004, p. 5).

However, in Peri's opinion, Birshteyn was much more "sophisticated" (personal communication, 5 Nov. 2005). Thus, "Expectation" (Dervartung/ Tsipiya) may well be conventionally linear, with a beginning, middle and end, with the type characters of an overworked and overwrought father and a caring, very maternal mother as seen by a seven-year-old child (like the unhappily ending "Stories for Jewish Children" by Sholem Aleichem). Moreover, the story concludes with an ironic caress: the child narrator is rocked to sleep by a lullaby, seemingly far from the anxiety of his surroundings. In this it has a similar ending to "On the Other Side of the Bridge" (1910) by the mainstream Realist and Naturalist Yoysef Opatoshu (1917: 148, 1966: 89). But the outside world is dark and vaguely threatening, much like that in an early Brenner story, where the landscape from the window of the hero's train is blurred by snow, unidentifiable, Gentile and hostile (Bakon 1985: 145, 32). It is quite unlike the "laughter and tears" formula of Sholem Aleichem but expresses a hard-hitting "negation of Exile": the home (in Birshteyn's Poland?) is desperately poor and the joys are few only a very occasional "slaughtered goose" for the Sabbath (reminding one of the "Slaughter of the Innocent Sheep" in such a story as "Veger," (1969: 127) as well as in "Expectation" (1969: 83). Still, the father is elevated to the rank of a "witch doctor" (a kishuf-makher) in the eyes of his son (1969: 87) because he can speak "deaf and dumb" language to the "unexpected" guests knocking eerily on the door of "home." These turn out to be nothing more than simple, indigent and handicapped Jews (1966: 88); as Bashevis-Singer would have it in My Father's Court, they are types of the "Storybook Beggar" (an evyen fun a mayse-bukh), half-miraculous and half-miserable (CD of Bashevis-Singer's In mayn tatens bes-din shtub [In my Father's Court], New York: Forverts, 2005).

Strangely enough, "Expectation" first came out in Hebrew in 1966 as the title story of a pocket-book volume in the Tarmil (or "Bookbag") series, though Birshteyn was still adapting himself to the language and, most probably, only thinking about 
becoming a fully successful Hebrew writer. Along with Yosl Bergner, he must have been busy hobnobbing with the intellectual leaders of his new-old homeland (Roskies 1995: 333-334 and "Yosl Bergner's 'Shpatsirn shifn' in Yafo,"Forverts 2004: 13, 22), including Menakhem Peri and Nissim Aloni, a Hebrew dramatist who, as a Sephardi from Bulgaria, knew no Yiddish. Nevertheless, at the prompting of Birshteyn, who read and explained his Yiddish text to him (just as Bashevis-Singer must have done for his English translators), Aloni translated "Rolider's First Journey" (Nesiyato harishona shel Rolider, 1970, from the manuscript of the unpublished [?] Rolider's ershte nesiye). He was even on the lookout for much less well-known translators like Khaya Vered, who was comfortable with shtetl symbols and could render troubled anticipation in a straightforward Hebrew.

The story's Yiddish publication, then, had to wait upon "The Coat of a Prince" in 1969, in which the language was masterfully colloquial, the pungent, rambunctious styles of Sholem Aleichem made rough and ready and unsentimental. In other words, it still featured pat characterizations by trait - "a peasant with a chin awry" (1969: 84) - but it also shows this peasant as a potential "pogromtchik" who doubts that "Little kikes" (zhidkes) could understand a "party" (simkhe in both Yiddish and Hebrew) in which "blood didn't flow" (1966, 1969: 89). It is worth noting that Vered renders "kike" by yehudon, using the same diminutive as the mild (and modern) depreciation of shmanmon-shmanmonet ("pudgy") and the unambiguously tender usage of M. Ravid, another of Birshteyn's journeyman translators, who had used the diminutive in evoking the speech of a "Children's House Teacher" when sending a charge (yaldonet, 1959: 39 ) to sleep in Birshteyn's "Kibbutz novel” ("On Narrow Walkways," Oyf shmole trotwaren / Bamidrakhot tsarot).

Birshteyn's new circles, both in Geva, his left-wing kibbutz (fictionalized as "Yalon"), and throughout Israel, were discussing communal values; to participate fully in the discussion, he wrote what was to be the first novelistic exploration of these themes in Yiddish (in 1958). Moreover, he placed the novel with the prestigious house of Y.L. Peretz in Tel Aviv, the foremost Yiddish publisher in Israel. Thus, he had arrived, only a few years after ascending to the new homeland, after first formulating "Yung-Yisroel," a literary group of Yiddish writers from "Exile" ("abroad") now transplanted to the new state (Roskies 1995: 330). Unexpectedly, maydele with the Yiddish diminutive was to become even more widely current than the Hebrew suffix of yaldonet, and Nurit, the name of the little girl, was to survive as Nuritke ("Sweet little Nurit"), as if to see to it that modern Israeli Hebrew had a Yiddish increase of emotional range. Nurit is merely seen to have "a mouth" in Hebrew (1959: 39), but this is a tellingly "sweet little snout" (piskl) in the language of the shtetl (1958: 47).

The praise of kibbutz values sung by Moshe Shamir in He Walked in the Fields ( Hu halakh basadot, 1947) was Birshteyn's main target when he concluded that the disciplined community was not emotionally whole (and incompletely "Jewish") and was instead ideologically stultified. In the first place, such an "Anglo-Saxon" intellectual as Daniel feels like an "outsider" (a droisendiker, 1958: 43) in it because he is too sensitive and inward to be easily "absorbed." This character can lie on his bed and feel overcome by non-ideological feelings - "...he gave himself over to the province of blood and ancient force" (89) just like the peasant in Dervartung/Tsipia. Likewise, the kibbutz is not an arena for cold and scientific breeding as it might want to advertise. It is a scene for the slaughter of a bull in the manner of the tragically undervalued Yiddish writer 
A.M. Fuchs (1961: 3, 15; Birshteyn 1989: 171-173 and 2004: 111-112), in which the animal's head is covered with a black sack (like a monk's cowl during the Inquisition), in which its blood flows both constantly and viscously (shvomik, 1958: 210).

But the man that does the slaughtering is himself slaughtered: Silberman, a concentration camp victim in charge of the life-and-death struggle over the bull, a character in search of a forward-looking home, must nevertheless suffer his son's suicide, despite his efforts to dispel the "melancholy" (di moyre skhoyre) of the past. This is another kibbutz crudeness needing urgent explanation - "Feivel, I know why. You were silent and said nothing. But Hitler was still hidden inside" (1958: 259). To "exorcize the demon," he recites the Prayer for the Dead (the kadish) in a scene betokening the intrusion of death, the Holocaust personified, into a superficially orderly kibbutz which lacks empathy for the despair under the surface.

The Kaddish represents a voice from the distant past, Aramaic not even Ancient Hebrew, and must sound "foreign and strange" to such avatars of secular modernity as the "Capitalist Kibbutznik" Dudek, the "Old Soldier" Haim and the "Outsider" Daniel. In fact, it may even seem "out of place" to Silberman himself, but he realizes that the Jewish sacrament of death must transcend kibbutz reality. The veteran kibbutznik Akiva sums up the strangeness by reference to the undefined form of "the dialect of the tribe": "We can't use the old words anymore and there are no new ones yet." In other words, no expressions have yet been invented to fill the void - and, he continues, "Just shutting up can get old and worn out" (1958: 259). In other words, proper verbal transitions to the new order, expressions both temporary and permanent, have not as yet been found and Birshteyn's kibbutz "glossary" at the end of his book is solely informational and could never provide guidance to handle life and death (see 1958: 301).

Daniel contemplates the prayer and concludes that "a kaddish...must be in a language that one doesn't use everyday. Maybe that's why pious folk stick to Yiddish [as the language marking out a secular zone for purposes other than prayer], so that their prayers [in Hebrew] can't ever be worn away" (1958: 259). However, Hebrew as the secular language of Israel was to tread over - and confuse - this border; in order to make it nonetheless special, to give it the uneroded resonance of transcendental purpose as well as historical suffering, Birshteyn found it likewise necessary to "mix meat and milk," to make room for the Jewish resource of Yiddish.

After a ten year gap in which he left the kibbutz for the "free market" life of a bank official and a professional writer (Roskies 1995: 331), he wrote about the transcendence of ideology in "Rolider's First Journey," an absurdist depiction of what a "recruiter's mission" (shlikhut) actually meant. It didn't mean the "rare good luck" of escaping from the deadening routine of kibbutz life in order to "preach Zionist ideology" abroad (1958: 265).

Rather, it meant the occasionally indiscriminate search for Jews in the Australian Diaspora ( $g a l u t$ ), the skill of sniffing them out in their hiding places. Of course, some of them are not in hiding, especially the openly religious ones, but these can be bewilderingly eccentric -and even indecisive. Others are given to such secular Yiddishist enthusiasms as theatrical declamation, illustrated with clownish, hilarious expressionism by Yosl Bergner (1970: 16). Some have vaguely (and comically) national and Zionist feelings and still others are more attached to the Australian village of the Gentiles ("Valhalla") and are barely Jewish themselves. Peter Norton, for example, is 
blond and blue-eyed and carries around a surfboard even on the kibbutz, just like a "California Aryan."

Nevertheless, this highly "assimilated Jew" (mitbolel) is as much of "a collector of dreams" (34,36, asfan khalomot) as any ghetto luftmentsh and Rolider must feed the dream in any way he sees fit - with a compassionate shilling tossed to Peter on the steps of city hall. He identifies (and identifies with) the hidden Jew despite the formulaic and trite warnings of the establishment Jew Betzalel Betzalel (whose last name should be pronounced "correctly" on the final syllable despite an "incorrect" - and Ashkenazic - first name stressed on the penultimate): "The Jewish state needs effective manpower, practical and resourceful. People who know what they're doing and what they want (39)." "Like Betzalel himself," Birshteyn continues with a conventionally laughable phrase - "His father came to The Land in order to die there but nevertheless managed to marry twice and establish a generation of four sons and two daughters (39, my emphases)."

Birshteyn knew his Zionist clichés and the content behind heavily indoctrinated kibbutz members like Shlomo Belfer - "Hess, Pinsker, Herzl, Feierberg and Brenner" (31). He knew how to make fun of a past in which the Sabbath, a religious rest day, becomes "property" along with the kibbutz acres; it can be "saved up for a rainy day," so that Belfer can boast - "I own (and foreigners don't) 180 Sabbaths" (31), compensation for "overtime" in compensation for "Sabbaths worked." (The same kind of sacrilege is Udi's applauded denial of the value of Scripture in 1958: 52). Likewise, the "homebound" Belfer as well as the "envoy" (shaliakh) Rolider can mourn "assimilation" (hitbolelut) and put a spin on Feierberg's Whither? question "Whither have our ideals of bygone years disappeared?" (32). Akiva of “On Narrow Walkways" answered that "revolutionary ideals" have died out with the tolerant mellowness (and cynicism) of age (1958: 140). For this reason, "Rolider's First Journey" ends in a funeral and a kaddish, not a hora, a joyous circle dance of Independence. For this reason, too, Rolider is still on his first mission and has not as yet "returned home" (86). For this reason, moreover, he may stay away forever and his "first journey" may also be his last. The final perspective is wandering and death in tune with a life filled with comical quirks and casual meetings.

Imitating this flow, Aloni's paragraphs, based on Birshteyn's dictation rather than on his formal text, often proceed breathlessly and unbrokenly in the speech of a dramatist aiming at simultaneity of thought and action. For example, while Rolider prepares for a funeral (the book is full of funerals!) in an Australian cemetery, he thinks of "a full-belly dance" as executed by Aborigines (47); in the same "stream of consciousness," Peter Norton, for his part, both worries about the difficulty of "ascent" to Israel and broods on a vision of this dance as performed by his father in the midst of the natives (48). Another spoof of the hora?

A paragraph may ebb into a character vignette: that of Belfer's father, for example, whose blood ties give him the right to live his life out on the kibbutz. However, he feels his stay to be precarious and thus finds his "soul mate" in the equally precarious Norton, whose dreams are off the regular course - "I will sing to my people from my grave," he parrots in an ill-understood Yiddish $(55,73)$, which he seems to think is the language of Israel.

Such a paragraph, without dancing or other movement, may focus on the lyrical and non-dramatic words and images of "time and dream," as an Aborigine-Preacher 
puts it (72). Carrying the same melancholy on a static Israeli bus seat next to Norton, Martsin Goldman discourses on "the myth of the lonely bird turned into a Bedouin" (56-57), symbol of wandering within the "national homeland."

"Veger" is a variant extension of this wandering: it portrays a deadlocked and dead-end life, so that its paragraphs and words snowball synoptically into a catatonic shiver, ending in a "freezing-blue and trembling synopsis" (1969: 166). This is more than just the result of staying in the water too long in Veger the survivor/victim's first test of competitive fortitude (back on p. 126, at the beginning of the story); the reader makes many such connections and realizes that Veger has trembled all along, even in his seemingly purposeful and dogged reading of the ultimate pessimist Schopenhauer. He does so in English (Peri 2000: 24) because his native German only re-asserts the trauma - "I'm still escaping from Germany," he explains to his fellows in the military camp (for the "stateless"?) in Australia (1969: 136). ("But he doesn't like English either," complains a Canadian ex-nun on the kibbutz [1969: 165]. What's more Yiddish, even though Jewish and non-threatening, is also disqualified because too similar to German).

The story is full of such symbolic (and fetishistic) obsessions: another example is his decision to choose "Yalon" because it has a piano on which he can vent his crazed pain, as if to drive away "the blond beasts" chasing him - as if to repeat the rhythm of Auschwitz shared by musical SS officers and prisoners alike (see Krutikov 2006 [April 21], Forverts, p. 17, p.22). But the most integrative symbol, both Jewish and general, is the head of a dead steer picked up from an Australian base "walkway" by Veger for the purpose of illustrating "how man is derived from monkey" (Peri 2000: 35). In other words, it signifies the universal death's head underlying Veger's life and is juxtaposed, in the very same paragraph, with an Australian piano. The same officer who finds the "teaching" skull under Veger's camp bed also listens to him play in the dining room and suggests, shockingly, that he give up Mozart and Bach for a rousing popular song. Moreover, and this is key: the sober movement of Birshteyn's Hebrew (Peri 2000: 31) carries forward the black humor of his Yiddish (1969: 141).

At the same time, Birshteyn revises the immanent, omnipresent and supportive Yiddish paragraph within the Hebrew. In the first place, whereas the important fact of "ascent to Israel," to a new homeland and a new life, merely introduces the original (1969: 139), it is shifted to the climax, to the end, in the language of Israeli statehood (the opposite of Australian "statelessness" and the final historical say, see Peri 2000: 30). From this rhetorically strong vantage point, it becomes transitional to a new paragraph as split from the longer Yiddish "breath group." Then the restatement is trimmed down to emphasize Veger's extreme uncertainty (Peri 2000: 30), a foreshadowing of the character's shivering at the story's end - so that paragraph structure mirrors the final form of the composition. Moreover, the split from the Yiddish and the creation of a short, climactic Hebrew segment points up Veger's pathetic and perverse longing: the "potato soup" (Kartoffelsuppe?) served in the kibbutz dining room "reminds him of his boyhood" (2000: 31).

Veger could have had what Raymond Queneau, in his 100 page recasting of the same paragraph (in Exercises de style, 1947), called a "skelton-like neck" (un cou squelettique, 15) and, with a bit more subjectivity - the quality that enhances and reorders paragraphs - "the big, scrawny neck of a plucked turkey" (un grand cou de dindon deplume, 25). Of course, Birshteyn had too much affection for his characters 
to ridicule them - and this folk feeling is a part of the Yiddish tradition, most particularly Sholem Aleichem. But he nevertheless indicated comical disproportions in the pointed paragraphs of the lyrical "short shorts" (sipurim ketsartsarim) he read aloud over Israel Defense Forces radio (the famed Galey Tsahal, see Roskies 1995: 335 and Birshteyn/ Peri 2004: 371).

Thus, for example, Birshteyn's "gestural story" combining the "tactile" and the "visual" in Queneau's paragraph taxonomy $(1947: 89,91)$ - "How a Story Is Made" (Vi azoi vert a mayse? 1989: 25-27) becomes the somewhat colloquial Hebrew "How a Story Is Cooked up" (Eykh mitbashel sipur, 2000a: 189-191). By this time (the new millennium), he was doing all of his own translation and revision and reshaped the Hebrew version radically, so that the first three paragraphs, narrating the arrival of his cousin and wife at his home in Jerusalem, make a streamlined, dramatic and oral highlighting in the split Hebrew from the much more extensiveYiddish block - "While walking towards me, [my cousin] rested his heavy, broad and open hand...on the head of his short wife - so short she only came up to his hips" (2000a: 189 from Yiddish, 1989: 25).

This hand makes the formative gestures of the incident: it is later identified with the weak handshake of a dying "townsman" or landsman (1989: 26) and then merges with the repeated evocation of the cousin's gesture in a final re-interpretation. Now it is punctuated with a question mark in Yiddish, casting doubt on the possibility of any story at all, and the unpunctuated, declarative and optimistic Hebrew, which opens the vista of a "good story" overcoming crisis (2000a: 191 from 1989: 27). In this way, death intrudes into the comical disproportions and ruffles and pits the smooth linguistic surface, lending tensile strength and near philosophical paradox.

Consequently, as Birshteyn wrote in an epigraph prefacing his last story collection, the posthumous "Stories from the Realm of Tranquillity" (Sipurim meeyzor hashalva, 2004), he imagined his own funeral as ridiculously "tidy" and "cultured" on the outside but "nitty-gritty and deathlike" in reality: "I raised my head from my coffin and saw someone following me and crying. I saw a little bald man." The miserable mourner was one of Sholem Aleichem's "little people," the heroes of Birshteyn's vignettes and sketches.

One such is Marcus the Tailor (the stock figure of Der shnayder in Yiddish lore) from Birshteyn's shtetl of Biale-Podolsk, Poland, and the main speaker of "The Tale of a Political Meeting" (Sipur bemifgash politi, 2004) to which the narrator hurries before he is stopped: "Remember to tell them that we're real people, have a real state and need a real government, not an imitation" - the excitation and the repetition are typically Yiddish, a fact which is stressed by a translation into the Yiddish of the above outspokenness (2004: 125). Moreover, Birshteyn brings the habit of Yiddish compounding into a jocular, Hebrew surface, according to which another village denizen supports his divine scholarship with the "Straw-trade" ("Trade in Straw") from Shtroy-miskher or kash-miskhar (instead of miskhar kash, the normal Hebrew compounding order, 2004: 125).

Birshteyn's uncle, in the same village company, is puzzled by thoughts of authenticity and can only respond by dumbly "steering his beard into the wind before him, without noticing the Sabbath Candles in his path. The beard catches fire ["is lit," nidlak from Hadlakat hanerot, "the lighting of the candles"] and roars into flame because of the dryness of the straw" (2004: 127). In other words, the candles (in the 
Menorah, a symbol of the Zionist State) fulfill the words of Marcus the Tailor, burn away the wretchedness of Birshteyn's uncle, and "make hay" rather than "straw" of the divine scholar's profession. Thus are traditional, religious symbols converted into secular and political ones and what was a neshome yeseyre or "special soul" is turned into the liberated and "soulful laughter" of joy, the quality that Birshteyn wanted to project to the Israeli soldier.

Blessing, then, is the meaning of the rain pelting a Jerusalem bus $(2000 \mathrm{a}: 17,57)$ and the central tendency of both Yiddish and Hebrew collections, titled so similarly that one is tempted to believe that the Yiddish optimism - not merely black humor - passed over directly into the Hebrew: Dayne geslakh Yerushalayim: kleyne mayses, 1989 ("Your Streets, Jerusalem: Mini Stories") became Sipurim rokdim birekhovot Yerushalayim, 2000 ("Stories Dancing in the Streets of Jerusalem"). What's more, this is dancing of cultural as well as political independence.

However, independence has its messy side: the street is crowded with congestion and pollution (plus the rain), and it is more comfortable to sit inside the bus as a bonafide passenger; the driver must close the door, somehow "putting a damper" on the blessing, though not canceling it (2000a: 56). Similarly, even though little Yankele takes on stature by carrying the Israeli Independence flag (Birshteyn/ Peri 2004: 223), and even though he dons new clothes for the celebration, his joy is sobered, inhibited: "Now I have a new patch," he notices, referring to the medal of honor on his clothes (2004: 224). The patch in fact covers over much horror - the Jew still covered with the "yellow patch" (Di gele late) despite the protection of a state.

Peri describes Avrom Reisen, the Yiddish poet and storyteller who created Yankele along with a career in the literary Warsaw of the turn of the previous century: "At this time, Reisen was a young writer who had left his house to catch a breath of fresh air, who now dreamed of the day when his name would resound in every Jewish home. This breath meant 'being seen' while stretching high to wave the flag" (Birshteyn/ Peri 2004: 364-365). However, as much as he extended himself, Reisen, like Birshteyn, could not halt the degeneration of value - of ideals, both secular and religious; witness the stories in Humoresken 1920; witness, too, Birshteyn's long narratives.

\section{Novels of Crisis, Normality and Circus}

In 1983, the Tel Aviv Stock Exchange crashed, wiping out the savings of many Israelis, many of them retired and living in old age homes (or moshavey zkeynim), also housing many new citizens who were survivors of the Holocaust. The country had to pull together and knew that it couldn't afford the capitalist luxury of private banking competition. Instead, banks were nationalized and unified (see "Israeli Investment, "p.1 on the Internet (Ahavat Israel 1995-2005).

Birshteyn, had begun the Yiddish version of "The Beneficiaries" as early as 1976 (titled Der zamler or "The Fundraiser and Collector," final Yiddish publication only in 1985) and was keeping track of the economic growing pains so closely that he actually predicted the crash. Whatever was "grotesque" in the behavior of its characters also corresponded to the dislocations of reality, to the wildness of hope and the obsession with gambling (see comments of Peri on the back of Hamutavim 2000). In an interview conducted during the days of the manuscript, Peri characterized Birshteyn's creativity as "the gliding from reality to fictional expression" (Glisha 
mehamitsiut lamitsiut hasipurit, Birshteyn /Peri 2004: 324). Both the real and the fictional were in perfect harmony.

From the manuscript of the above Yiddish publication, Peri brought out his Hebrew version, first in 1982, only one year before the collapse itself, and later in 2000 as an intensive response to a large potential readership who knew no Yiddish and might nevertheless benefit from the book (personal communication, 5 Nov. 2005). After all, it seemed an ideally relevant description of the Israeli condition as suspended over the quaint, dreamlike and insecure shtetl despite geographical removal from the Eastern Europe - Biale-Podolsk - of pious "Grandfather Israel." But the novel is "not solely an Israeli reincarnation of Sholem Aleichem's Menakhem Mendl," the luftmentsh and stock market broker of "Classic" Yiddish satire. It was also a "transmigration and transformation of the Holocaust," an internalization of cruel absurdity (see Birshteyn/ Peri 2004: 387, 392) in which WW II survivors, either drunken with pride in their own state or skeptical like Veger (also a character in Hamutavim), are pried loose from their war reparations in order to free them for the Stock Exchange.

The Hebrew title is plural (-im) and points to the central characters of the novel, not to the singular "Fundraiser or Collector" (Gelt-zamler) Halevi, the bank officer in charge of stocks, bonds and antique promissory notes, but to the recipients of the benefits, to "Beneficiaries" like Solomir, whose recruitment of bank customers to the "folk capitalism," the shareholding "philosophy" of Kenard Berensohn (113), pays for his museum of Yiddish and Jewish memorabilia - making him a "collector" in the sense of curator. His collection features various portraits of Sholem Aleichem, spanning his life, death and immortality $(89,131,148)$ and thereby illustrating the gargoyle-style humor of the book's first sentence - "Shmuel Solomir died laughing in our bank" (1985: 9; 2000: 7). Showing Peri's “buddy-buddy" native-born ease, a character gives the dead man the Israeli diminutive nickname of "Shmulikl" (154).

This lightheartedness points to the book's identity as a comedy in which a dead Solomir can't have the last word. Instead, a life-giving hilarity, a gallows humor, issues from the picture of him climbing into the ancient sarcophagus of his museum in order to enjoy a snooze (152). In addition, although the depositors temporarily discredit "K.B." the benefactor, they are persuaded to restore their confidence by Halevi in a pompous German or Germanized Yiddish later translated into Hebrew - "[What we need is] trust [bitokhen], my dear madame, trust." Then, just before his own death, Solomir renders and generalizes the advice in modern Yiddish and Hebrew - "[Yes], Bitukhen/Bitakhon, my dear sir, Bitukhen/Bitakhon" (1985: 224; 2000: 156). As Sholem Aleichem's Tevye the Dairyman says - "A Jew must have faith" (or "trust,"bitukhen).

So the novel ends in the restoration of the courage to meet the real world head on because such confrontation can provide the foundation from which the ladder of optimism may climb - and the rungs of the ladder are made of Yiddish as subtext, a Yiddish which makes the Hebrew laugh, sometimes sardonically, sometimes betokening death and suffering, and sometimes introducing hope, its opposite, beneath a sober, confident, "nationally approved" and up-to-date Israeli text. Thus enlivened, the crash of the stock market may well seem crucial, but it nevertheless resists permanent crisis. The language, a revived Hebrew maintained intact, must go on.

Peri hallows this normalcy in the face of Birshteyn's characters' withering (and near trite) belief that "life in Israel is a jungle" (2000: 80) and "the world is stupid" (100). In fact, the latter - metumtam - is a genially accurate rendering of $A$ yoldishe 
velt (1985: 143), which Weinreich's Modern Yiddish-English Dictionary defines as "a simpleton's world": it is a well-motivated and suggestive spin-off of the root tmtm, signifying "stupefaction, stupor and stupidity" according to Alcalay's Hebrew-English Lexicon. In addition, he delivers humorous Yiddish folk wisdom in the overcoming of crisis and the resuscitatation of the Hebrew: the good advice of "eating dirt while staying happy" (literally, "chewing straw...") leads to the word-for-word Israeli Lilos kash [ like the "straw trade" in Poland] velehishaer sameyakh (2000: 117) from Keyen shtroy un blaybn freylakh (1985: 166). In fact, the advice has been largely accepted, so that Peri can be seen as contributing to its canonization. Of course, purist critics of Birshteyn/ Peri have pointed out that "the Hebrew smacks too much of Yiddish," but this is a Jewish strength rather than a weakness (see Roskies 1995: 335).

Accordingly, the Israeli irony in the word sameyakh - "the bank went berserk for joy" (babank haya sameyakh, 2000: 143) - is traditional: Bialik, who did so much for the modern formulation of Hebrew, also briefly wrote in the Yiddish evocation of $A$ freylakhs ("A Joyous Wedding Dance," see Waldinger 2003: 262-263), and its adjective freylakh is a tongue in cheek reference to "happy pogrom activists" in such a phrase as Di pogromtchikes zenen geveyn freylakh (or even gemakht sameykh). In Roskies phrase (1995: 332), the word is "an echo from the ['usable'] past," both wildly happy and bitterly sad.

The intensifying adverbial harey ("after all") is considered typically Israeli and untranslatable (according to Galia Baron, Department of Hebrew, Defense Language Institute, Presidio of Monterey, CA, May 4, 2006). However, it too is generally Jewish as an essential formula in the marriage service - "Behold, thou art consecrated unto me..."I Harey at mekudeshes li..."(see Singer 1917: 447). Prayer Book. Moreover, Bashevis-Singer, in a story about the marriage of a prostitute (and nothing can be more ironic), gives the formula a Yiddish twist - "the regulation hareyat" (CD of " $A$ Khasene"[A Wedding]. New York: Forward Association, 2004). Likewise, Peri and Birshteyn are very matter of fact about the expression, given its almost automatic role in Israeli usage, but their rendition of a character's low community standing because he's a non-scholar - "After all, I'm [just] an ignoramus" (2000: 101) - expresses a general Jewish value.

Peri (2000: 101) hyphenates this judgment-Am-Haarets or "People of the Earth" (rather than "of Heaven") just as in literary Yiddish, though its spoken form as codified by Weinreich is one unitary and unbroken word - amorets. Moreover, on the original side, he adds a non-traditional, oral hyphenation to Israeli automatisms like Ma-zot-omeret? ("What-does-that-mean?") and Ben-adam ("Son-of-Adam") (2000: 89 ), thereby revealing a very modern understanding of the cohesion.

But Yiddish was transitory (and peculiarly transitional) and Birshteyn knew it; probably pained, he intended to find a literary way to make it permanent. So though he wrote the first version of "A Face in the Cloud" in Hebrew (Panim baanan, 1991) as the only longer work written initially in the language of pioneering, he later translated it (by himself) in the language of Galut or "Exile" (A Ponim in di volkens, 2000b). In other words, he had shaped himself into a full-scale "autotranslator" independent of "big name" mediators like Menakhem Peri and Nissim Aloni. Unapologetically, he was letting principled homelessness have the last word.

His hero, after all, was a Yiddish writer, Tirshbeyn by name (an anagram for "Birshteyn"?) and enjoying the company of "pen people" (penmentshen) like Yoysef 
Opatoshu (1991: 108) and Peretz Markish (2000b: 166). Moreover, at this stage in his fictional development, his "face" was turned to Poland (the "Cloud"?), where the Yiddish writer Borukh Glazman advised such writers to stay if they wanted to continue to create in Yiddish and secure "the future of Yiddish literature" (2000b: 165). So that would make Poland even better than the Land of Israel? (2000b: 176). Tirshbeyn (and Birshteyn) are clearly joking.

At the same time, he criticizes the sacrosanct "Zionist Enterprise": "What was Mr. Herzl thinking? That the Jewish people would find redemption after 2,000 years of Exile in the building of one house after another, one settlement after the other? In this way [kakh harey,1991: 165; azoy arum, 2000b: 281], he turned the Jewish people into foot-soldiers" - "like normal people" as Ben Gurion would say, using a Hebrew phrase (kakhol hagoyim) even in the Yiddish version. Consequently, it is Tirshbeyn's fate to range abroad: not only is he based in Cleveland, Ohio - he prefers this to Jerusalem - but he raises funds in China - of all places - for the "future" of Yiddish in Poland.

However, though Zionism can no longer be taken seriously as an ideological solution to Jewish homelessness, it remains a good source of comedy. Referring to Sholem Aleichem's willingness to lecture "on the Zionist circuit," Roskies (1995: 173) zooms in: "Zionism brought the carnival back to town, with the storyteller as master of ceremonies, his repertory taken from the audience itself and designed to uncover the pattern of their lives." Accordingly, in the early pages of his book, Birshteyn creates an ironic juxtaposition between one of his Yiddishist eccentrics, begging a handout, and a Zionist skit performed on a street stage nearby. The beggar is ridiculous and somewhat mad while the heroine of the skit is a "lusty and busty Zionist lass," foolish in her self-confidence.

Of course, genuinely healthy universalism exists even on the nationalist kibbutz. The very "Canaanite" Uri Zamir (the name of Bashevis-Singer's Israeli son), shod as he is in "Old Testament Sandals," still applies the lessons of his Lithuanian religious academy, steeped in the "morality movement" of Israel Salanter - its preaching of love for humanity, plain living and purification through the community (2000b: 352). But these guidelines in no way satisfy the doubts of Shmuel-Yoysef Noibish (a ridiculous combination of the Nobel Prize winner Shmuel-Josef Agnon and a "Nebish," a "pitiful nobody" in Yiddish). He imagines Yiddish as a purified tongue, steering clear of "provinciality, "reaching out to the world and untainted by the "brotherhood of death" (2000b: 169). Unfortunately, though, Noibish is chained to a devastating reality, wants to "chronicle the decline and fall of Polish Jewry" and commits a bumbling suicide himself, his chair turned to the Jerusalem street (2000b: 177, 359). Yiddish has indeed "stopped laughing" under the weight of the "indescribably dark disaster "exercised by the Holocaust. Moreover, the Hebrew can point out that "sunsets and pink twilights" (shkiyat hashemesh vedimdumin vrudim) have romantic overtones, but "there's no beauty in such devastation -except in the beauty of Yiddish" (1991: 111 and 2000b: 181). In short, Yiddish remains the ringmistress.

It is the "poetess from Brisk" Sara Yorberg who cracks the whip and makes the circus move. She is its Yiddish "head priestess" at the same time as Tirshbeyn's "royal consort" (1991: 136: 2000b: 225) who must dedicate herself totally to the goal of assuring the dominion and the domain of Yiddish literature - and thus steering clear of the competing claims of pregnancy (1991: 165; 2000b: 281). But her "king" is "a 
monarch of all he surveys," especially the senses: he "kisses every member of her body, even including the hair under her [priestly] arms," with Rabelaisian abandon - and Saturnalian comedy (2000b: 225).

Nevertheless, Sara Yorberg is incapable of competing with the strangely fascinating yet completely unremarkable (and "valueless") D.D., an inhabitant of the big town of New York (and not a small Polish shtetl); she learns Yiddish for no other reason than to decipher Tirshbeyn's letters to her rival. What's more, it is her "lock of pubic hair" that Sara's supposed "king" packs in his suitcase for China as a relic along with the maxims of Kant (1991: 365). In fact, "the Sage of Koenigsberg's" portrait at the beginning of the book determines Tirshbeyn's world-view even more than a Jewish authority; it is the universalist counterpart of Sholem Aleichem in "The Beneficiaries," and "transcendental egotism," over and above merely "tribal" Yiddishism, is nourished by the lotus pond of sex together with the memory of D.D.'s laughter (2000b: 366). This is the new, surprising and transnational rootedness of "A Face in the Clouds."

Neither this "roadside attraction" (the title of a novel by equally zany Tom Robbins) nor any other major work by Birshteyn has been translated into English though "A Face in the Clouds" has come out in German, the language of the Holocaust, and in Chinese - presumably because of Tirshbeyn's fundraising in China. But righting this wrong requires the especially close attention of every potential translator: not only to the layering of discrete languages -originally either Hebrew or Yiddish and now with the accretion of English - but also to the stages and levels of signification, to the words, sentences and paragraphs whose accumulation brings about the "end." These are "semaphorically" distinct in each of the languages involved. Likewise, there is a natural transition from a "short-short" recited to the Israel Defense Forces to the broader, novelistic frame: a short romp in the Jerusalem streets, during which an ultrareligious seminary student is forced to share a taxi with a secular journalist of the "female persuasion," turns into a comic scene in the progress of "A Face in the Clouds" (Birshteyn 2000a: 39; Birshteyn 2000b: 50).

This potential translator must understand completely - viscerally as well as intellectually - that the average Israeli is preoccupied with death, not only as a daily reality in which the number of terrorist attacks is growing wildly (50\% over last year at this time, "the cruelest month," see Forverts 2006 [April 14], p. 2), but also as an intrusive (and often unwelcome) memory of the Holocaust. This intrusion is integral to Israeli history, to the extent that Idith Zertal, in her recent Death and the Nation, emphasizes that "the Jewish state...emerged from the ashes of a program of extermination" in which Eichmann, an engineer of the program, is still alive. Consequently, "obsession with death and martyrdom has vitally shaped the way Israelis view themselves and this state" (Kimmerling 2005 [Jan. 10], The Nation, p.23).

But there is another category of death beyond the irrevocable, physical suicide of Silberman's son in "On Narrow Walkways." There is the sometimes comic Tlishut or "uprootedness," the death of will and purpose of such modern "heroes" as Yekhezkel Khefets (ironically, "desire") in Brenner's Shekhol vekishalon (1919, translated as "Breakdown and Bewilderment" by Hillel Halkin). Birshteyn's tlushim (deracinated souls veering away from the center and thus "eccentric") include not only the downin-the-mouth intellectual Daniel or the broken-down Veger, but also the "kibbutz surfer" Peter Norton and the comic and weirdly optimistic Solomir and Tirshbeyn. It is even possible to see Birshteyn himself as a talush: as authorial persona, he is both 
witness of and participant in the traumatic absurdity he narrates. Such trauma is the crux of the matter for literary translation.

\section{NOTES}

1. Translations from Hebrew and Yiddish are by the author. The transliteration system throughout is that of YIVO (Yiddish Scientific Organization).

\section{REFERENCES}

Alcalay, R. (ed.) (1965): Complete Hebrew-English, English Hebrew Dictionary, 3 vols., Ramat Gan, Massada.

BAKоn, Y. (1985): Haktavim hayidiim shel Yosef Haim Brener, Beersheva, Ben Gurion University.

BAshevis-Singer, Y. (2005): "A Khasene" - In mayn tatns beys-din shtub, CD read by David Rogow, New York, Forward Association.

BASHEVIS-SingeR, Y. (2005): "An unhaymlakhe shayle" - In mayn tatns beys-din shtub, CD read by David Rogow, New York, Forward Association.

Birshteyn, Y. (1949): Unter fremde himlen: lider, Melbourne.

Birshteyn, Y. (1958): Oyf shmole trotwaren, Tel Aviv, Y.L. Peretz.

Birshteyn, Y. (1959): Bamidrakhot tsarot, translated by M. Ravid, Safed/Tel Aviv, Hamatmid.

Birshteyn, Y. (1966): “Tsipiya," in Tsipiya veod sipurim, translated by Haya Vered, Tel Aviv, Sifriyat tarmil, pp. 77-91.

Birshteyn, Y. (1969): A mantl fun a prints, Tel Aviv, Y.L. Peretz.

Birshteyn, Y. (1970): Nesiyato harishona shel Rolider veod shney sipurim, translated by Nissim Aloni and author, with 8 drawings by Yosl Bergner, Tel Aviv, Sifriyat hapoalim.

Birshteyn, Y. (1982): Hamutavim, translated by Menakhem Peri, Tel Aviv, Siman kria.

Birshteyn, Y. (1985): Der zamler, Tel Aviv, Siman kria.

Birshteyn, Y. (1989): Dayne geslakh - Yerushalayim, Tel Aviv, Sifrey siman kria.

Birshteyn, Y. (1991): Panim baanan, Tel Aviv, Hasifriya hekhadasha.

Birshteyn, Y. (1993): Gesicht in den Wolken, Zurich, Raabe und Vitali.

Birshteyn, Y. (1999): Meng Long Mian Sha (Chinese translation of A Face in the Clouds), Shanghai, Fudan University Press.

Birshteyn, Y. (2000): Hamutavim, translated by Menakhem Peri,Tel Aviv, Hasifriya hekhadasha.

Birshteyn, Y. (2000a): Sipurim rokdim birekhovot yerushalayim, Tel Aviv, Hasifriya hekhadasha.

Birshteyn, Y. (2000b): A ponim in di volkens, Tel Aviv, Y.L. Peretz.

Birshteyn, Y. (2004): Sipurim me-eyzor hashalva, Tel Aviv, Hasifriya hekhadasha.

Brenner, Y. H. (1972): Shekhol vekishalon, with a critical essay by Baruch Kurzweil, Tel Aviv, Am oved.

Chaver, Y. (2004): What Must Be Forgotten: the Survival of Yiddish in Zionist Palestine, Syracuse, Syracuse University Press.

Estraykh, G. (12/02/05): “Leynendik Mordechai Tsanin's neviyes," Forverts, p. 14.

Even-Shoshan, A. (Ed.) (1975): Hamilon hakhadash, 3 vols, Jerusalem, Kiryat sefer.

Feldman, Y. S. (1986): Modernism and Cultural Transfer: Gabriel Preil and the Tradition of Jewish Literary Bilingualism, Cincinnati, Hebrew Union College Press.

Fuchs, A. M. (1961): Di nakht un der tog, New York, Der kval.

Harkavy, A. (Ed.) (1891): English-Yiddish, Yiddish-English Dictionary, New York, Hebrew Publishing Company.

Internet (Ahavat Israel) (1995-2005): Israel Investment.

Kimmerling, B. (2005 [Jan. 10]): “Israel's Culture of Martyrdom: a Review Article," The Nation, pp. 23-28.

Krutikov, M. (2006 [Apr. 21]): “Muzik in dem khurbn," Forverts, p. 17.

"Lillian Lux: an Obituary" (2005 [Jun. 25]): Economist, p. 86. 
Novershtern, A. (2004 [Jan. 9]): “Gilgulo shel meil bakhutsot Yerushalayim," Haarets, p. 5.

Opatoshu, Y. (1917): “Oyf yener zayt brik," A roman fun a ferd-ganef un andere ertseylungen, New York, Literarisher verlag, pp. 128-149.

Peri, M. (ed.) (2000): Antologiya khadasha, v.1. Tel Aviv, Siman kria.

Peri, M. (2005 [Nov.5]): Personal Communication.

Queneau, R. (1947): Exercices de style, Paris, Gallimard.

Roskies, D. G. (1995): Bridge of Longing: the Lost Art of Yiddish Storytelling, Cambridge, Harvard University Press.

Sholem, A. (1952): Wandering Star, translated by Frances Butwin, New York, Crown.

Sholem, A.(1953): Adventures of Mottel the Cantor's Son, translated by Tamara Kahana, New York, Henry Schuman.

Sholem, A. (1959): Motl Pesye dem khazns, vols. 3-4, New York, Tog-morgen zhurnal.

Sholem, A. (1976): Menakhem Mendl in Nyu York, Varshe, Viyn un Yehupets, introduced by Avrom Lis, Tel Aviv, Y.L. Peretz.

Sholem, A. (1987): Tevye the Dairyman and the Railroad Stories, translated and introduced by Hillel Halkin, New York, Schocken.

Sholem, A. (1999 [1920]): Blonzende shteren, Amherst, National Yiddish Book Center (Steven Spielberg Digital Library).

Siмкноviтch, S. (2006 [Mar. 17]): "Eli Shekhtman - tsu zayn tsenten yortsayt," Forverts, pp. 1617.

Singer, S. (Ed.) (1917): Daily Prayer Book (Sidur), New York, Bloch Publishing Co.

"Tsahal: tsol terror-atentatn vakst" (2006 [Apr. 14]): Forverts, p. 2.

Waldinger, A. (1999 [Jun.-Dec.]): "Yiddish Kafka," Journal of the Kafka Society of America, pp. 6377.

Waldinger, A. (2003 [49/3]): "Yiddish/ Hebrew Bilingualism: Genesis and Realization," Babel, pp. 253-274.

Weinreich, U. (Ed.) (1968): Modern English-Yiddish, Yiddish-English Dictionary, New York, YIVO/McGraw-Hill.

"Yosl Bergner's 'Shaptsir-shifn' in Yafo" (2004 [Dec. 10]): Forverts, p. 22. 